\title{
Proteome profiling of lipopolysaccharide induced L6 rat skeletal muscle cells response to flavonoids from Scutellaria baicalensis Georgi
}

Jin A Kim², Arulkumar Nagappan², Hyeon Soo Park², Venu Venkatarame Gowda Saralamma², Gyeong Eun Hong ${ }^{2}$, Silvia Yumnam², Ho Jeong Lee ${ }^{2}$, Suchismita Raha², Eun Hee Kim³ ${ }^{3}$ Paik Soon Young ${ }^{1 *}$ and Gon Sup Kim²*

\begin{abstract}
Background: Scutellaria baicalensis Georgi is a commonly used medicinal herb in several Asian countries like Korea, China and Japan for thousands of years. It has been reported to have various medicinal properties such as anti-microbial, anti-inflammatory and anti-cancer effects. However, the anti-inflammatory mechanism of S. baicalensis $\mathrm{G}$ at proteome level has not yet been reported. Hence, we performed a proteome analysis to study differentially expressed proteins and its anti-inflammatory role in lipopolysaccharide (LPS) stimulated L6 skeletal muscle cells response to flavonoids isolated from $\mathrm{S}$. baicalensis $\mathrm{G}$.
\end{abstract}

Methods: For that, $150 \mu \mathrm{g}$ of proteins from the L6 cells of the control (Vehicle only), LPS treated and flavonoid treated groups were separated using $18 \mathrm{~cm}, \mathrm{pH}$ 4-7 IPG strips in the first dimension and resolved by $12 \%$ linear gradient SDS-polyacrylamide gel electrophoresis (SDS-PAGE). The silver stained gels were analyzed by using progenesis SameSpots software and twenty six differentially expressed protein spots $(\geq 2$ fold, $p<0.05)$ were selected for matrix assisted laser desorption ionization- time of flight mass spectroscopy/mass spectrometry (MALDI-TOF/MS) analysis. Also, the expression of COX-2, iNOS and Annexin A2 proteins were analyzed by western blot.

Results: Totally, 12 differentially expressed proteins were successfully identified by MALDI-TOF/MS and database searching, that's involved in inflammatory responses such vimentin, T-box transcription factor TBX3, annexin A1, annexin A2 and annexin A5. In addition, flavonoids inhibited the expression of COX-2, iNOS and Annexin A2 proteins in LPS-stimulated L6 skeletal muscle cells.

Conclusions: The findings revealed that the flavonoids from S. baicalensis G. directly protect the LPS stimulated inflammation process in L6 cells and, would be helpful to study further the muscle cell inflammatory mechanism. This is the first proteome study provide the anti-inflammatory mechanism of flavonoids from S. baicalensis G. in LPS stimulated L6 skeletal muscle cells.

Keywords: Flavonoids, Scutellaria baicalensis G, L6 skeletal muscle cells, Lipopolysaccharide (LPS), Two dimensional gel electrophoresis, Matrix assisted laser desorption ionization time of flight mass spectrometry (MALDI-TOF/MS)

\footnotetext{
* Correspondence: paik@catholic.ac.kr; gonskim@gnu.ac.kr

'Department of Microbiology, College of Medicine, The Catholic University of Korea, Seoul 137-701, Republic of Korea

${ }^{2}$ Research Institute of Life Science and College of Veterinary Medicine (BK21 plus project), Gyeongsang National University, Gazwa, Jinju 660-701, Republic of Korea

Full list of author information is available at the end of the article
} 


\section{Background}

Scutellaria baicalensis Georgi (Lamiaceae) is one of the most widely used herbs in Traditional Chinese Medicine (TCM) for thousands of years. It's possesses various biological activities such as anti-microbial, anti-inflammatory and anti-cancer effects [1,2]. The bioactive compounds present in $S$. baicalensis are the flavones like baicalin (5,6-dihydroxy-4-oxygen-2-phenyl-4H-1-benzopyran7-beta-d-glucopyranose acid), baicalein (5,6,7-trihydroxy2-phenyl-4H-1-benzopyran-4-one), scutellarin and wogonin (5,7-dihydroxy-8- methoxyflavone) and [3-5]. Wogonin, the main active component which exhibits anti-cancer activities [6,7], anti-angiogenesis [8], and also has been reported to inhibit cell growth and induces apoptosis in various cancer cell lines [9-11].

In addition, Baicalein, other major flavonoids in S. baicalensis G., widely used to treat cancer and various inflammatory diseases [12,13]. Baicalin inhibits various human cancer cell growth in-vivo $[7,14,15]$. Recent studies have demonstrated that the role of S. baicalensis G. in cancer cell line, including cell cycle arrest and apoptosis $[16,17]$. Our recent studies have shown that the water extract and flavonoids from Korean S. baicalensis G. inhibits cell cycle G1/S transition in A549 lung cancer cells [18] and inhibited inflammatory signaling pathways in RAW 264.7 Cells, respectively [19]. However, anti-inflammatory effect of Korean S. baicalensis G. in LPS induced L6 skeletal muscle cells using proteomic approach has not been studied. Hence, in the present study, we performed a proteome analysis of L6 cells after treatment with LPS and flavonoids Korean S. baicalensis G. and 12 differentially expressed proteins were identified by MALDI-TOF/MS. These proteome results suggest that flavonoids from S. baicalensis G. directly protect the LPS stimulated inflammation process in L6 skeletal muscle cells. To our knowledge, this is the first study provide the evidence for an interaction between flavonoids from S. baicalensis G. and LPS stimulated L6 skeletal muscle cells.

\section{Methods}

\section{Chemicals and reagents}

Dulbecco's modified Eagle's medium was purchased from Hyclone (Logan, UT, USA). Fetal bovine serum (FBS) and antibiotics (penicillin/streptomycin; P-S) were purchased from Gibco (BRL Life Technologies, Grand Island, NY, USA). Materials and chemicals used for electrophoresis were obtained from BioRad (Hercules, CA, USA). Antibodies to COX-2 and iNOS were obtained from Santa Cruz Biotechnology (Santa Cruz, CA, USA). Annexin A2 was purchased from Cell Signaling Technologies (Beverly, MA, USA) and $B$-actin was purchased from Millipore (Billerica, MA, USA). All other chemicals were purchased from AMRESCO (Solon, OH, USA) and
Sigma-Aldrich (St. Louis, MO, USA). All the chemicals used were of the highest grade available commercially.

\section{Preparation of SBWE and isolation of flavonoids}

Scutellaria baicalensis cultivated in Korea was obtained from the Animal Bio-Resources Bank (Jinju, Korea). The voucher specimen (\#00100B) was deposited at the Animal Bio Resources Bank, Gyeongsang National University. The flavonoids and plant material used in this study were supported by the Department of Chemistry, Gyeongsang National University by Prof. Sung Chul Shin. High performance liquid chromatography (HPLC) was performed as described previously [9]. The mass spectrometer was operated in the positive mode with selected ion monitoring using BioAnalyst ${ }^{\mathrm{T}}$, version 1.4.2 (AB Sciex, Zagreb, Croatia). Electron spray voltage was set at $5.5 \mathrm{kV}$, and the source temperature was $400^{\circ} \mathrm{C}$. Mass spectra were recorded between m/z 100 and m/z 1500 with a step size of $0.1 \mathrm{amu}$. Samples were stored at $-20^{\circ} \mathrm{C}$ until used for various cell culture treatments.

\section{Cell culture and evaluation of cell viability by MTT assay}

L6 Rat Skeletal Muscle Cells were obtained from Korean Cell Line Bank (KCLB, Seoul, Korea) and cultured in DMEM medium, supplemented with 10\% FBS and 1\% P-S, and grown in a humidified incubator with $5 \% \mathrm{CO}_{2}$ in air at $37^{\circ} \mathrm{C}$. The L6 cells were cultured in 12-well plates and incubated overnight. The cells were pretreated with 30, 60, 90, 120 and $150 \mu \mathrm{g} / \mathrm{mL}$ flavonoids for $1 \mathrm{~h}$ and then treated with LPS $(1 \mu \mathrm{g} / \mathrm{mL})$ for $24 \mathrm{~h}$. The cells were incubated in $100 \mu \mathrm{L}$ MTT solution $(5 \mathrm{mg} / \mathrm{mL}$ in phosphate buffered saline; PBS) at $37^{\circ} \mathrm{C}$ for $3 \mathrm{~h}$. The violet crystal deposits were dissolved with $500 \mu \mathrm{L}$ dimethyl sulfoxide and absorbance was read at $540 \mathrm{~nm}$ using an enzyme-linked immunosorbent assay (ELISA) microplate reader. All experiments were conducted in triplicate.

\section{Sample preparation for 2D-polyacrylamide gel electrophoresis (2-DE)}

Whole protein extracts were prepared from control, LPS treated, and flavonoids treated L6 cells. Briefly, cell pellets were resuspended in $500 \mu \mathrm{l}$ of lysis buffer (7 M urea, $2 \mathrm{M}$ thiourea and $4 \% \mathrm{w} / \mathrm{v}$ CHAPS) on ice for $1 \mathrm{~h}$. The lysates were centrifuged at $15000 \mathrm{rpm}$ for $15 \mathrm{~min}$, collected the supernatant and stored at $-80^{\circ} \mathrm{C}$ until analysis. The proteins in the supernatant was precipitated with $10 \%$ TCA $(\mathrm{v} / \mathrm{v})$ and incubated for $1 \mathrm{~h}$ at $-20^{\circ} \mathrm{C}$. The samples were then washed with ice cold acetone and protein pellets were dried in a lyophilizer dryer (SFDSM06, Samwon Freezing Engineering Co., Busan), dissolved in $500 \mu \mathrm{l}$ of sample buffer and stored at $80^{\circ} \mathrm{C}$ until further analysis. Protein concentration was determined by the $\mathrm{NI}^{\mathrm{m}}$ (Non-Interfering $^{\mathrm{TM}}$ ) Protein Assay kit (G-Biosciences, St Louis, $\mathrm{MO}, \mathrm{USA}$ ) according to the manufacturer's protocol. 


\section{2-DE and image analysis}

The $150 \mu \mathrm{g}$ of proteins from all three groups were rehydrated overnight using $18 \mathrm{~cm}$ IPG strips $(\mathrm{pH} 4-7$; Amersham Biosciences) at room temperature in the first dimension. The protein samples were focused with a Pharmacia Multiphor II separation unit (Amersham Biosciences) for $67.2 \mathrm{kVh}$. The focused strips were equilibrated twice for $15 \mathrm{~min}$ each time, first in $10 \mathrm{mg} / \mathrm{ml}$ dithiothreitol (DTT) and then in $40 \mathrm{mg} / \mathrm{ml}$ iodoacetamide (IAA) prepared in an equilibration buffer containing $50 \mathrm{mM}$ Tris- $\mathrm{HCl}$ ( $\mathrm{pH} 8.8$ ), $6 \mathrm{M}$ urea, 30\% (v/v) glycerol, and 2\% (w/v) sodium dodecyl sulfate (SDS). The focused proteins were then separated in the second dimension by $12 \%$ linear gradient SDS-polyacrylamide gel electrophoresis (SDS-PAGE) with a constant current of $25 \mathrm{~mA} /$ gel at $20^{\circ} \mathrm{C}$. Gels were run until the bromophenol dye front reached the bottom of the gel. The silver stained gels were scanned using Bio Rad GS-800 densitometer and analyzed by using progenesis SameSpotsTM 2D software (ver. 4.1, Nonlinear Dynamics, Newcastle, U.K.). Protein spots showing $\geq 2$ fold and $\mathrm{p}<0: 05$ changes in expression were considered as statistically significant altered proteins.

\section{In-gel protein digestion, MALDI-TOF-MS analysis and database searching}

The statistically significant protein spots were excised manually from each 2-DE gel and the protein was digested as previously described by [20] with slight modifications. The excised protein spots were proteolyzed in-gel with trypsin and resulting tryptic peptides were subsequently extracted and dried using a vacuum freeze dryer (SFDSM06, Samwon Freezing Engineering Co., Busan). Finally, the extracts were targeted onto a MALDI plate and MALDI-TOF MS were performed on a Voyager- DE STR mass spectrometer (Applied Biosystems) equipped with delayed ion extraction. Mass spectra were obtained over a mass range of 800-3,500 Da. For identification of proteins, the peptide mass fingerprinting data were used to search against NCBI non-redundant protein database using the Mascot program (http://www.matrixscience.com). The following parameters were used for database searches: taxonomy, Rattus; cleavage specificity, trypsin with 1 missed cleavages allowed; peptide tolerance of $100 \mathrm{ppm}$ for the fragment ions; allowed modifications, Cys Carbamidomethyl (fixed), oxidation of Met (variable). The proteins were identified as significant hits $(\mathrm{P}<0.05)$ by a peptide mass fingerprinting (PMF) ion search. To identify the correct protein from a Mascot results list, MOWSE score and species had to be considered.

\section{Western blot analysis}

The L6 cells were cultured in wells of 6-well plates were incubated in DMEM as the solvent control or, LPS treated, and flavonoids $(150 \mu \mathrm{g} / \mathrm{mL})$ for $24 \mathrm{~h}$ at $37^{\circ} \mathrm{C}$. After washing with cold PBS, the cells were lysed in RIPA buffer [1\% (w/w) NP40, 1\% (w/v) sodium deoxycholate, $0.1 \%(\mathrm{w} / \mathrm{v})$ SDS, $0.15 \mathrm{M} \mathrm{NaCl}, 0.01 \mathrm{M}$ sodium phosphate buffer, pH 7.2, 2 mM EDTA, and $50 \mathrm{mM} \mathrm{Naf}$ (as phosphatase ingibitor) and protease inhibitors]. The cell debris was removed by centrifugation at 14,000 rpm for $25 \mathrm{~min}$ and protein concentration was determined using a Bradford assay (Bio-Rad). Proteins were separated by $12 \%$ SDS-polyacrylamide gel electrophoresis (SDS-PAGE) and transferred to a polyvinyldene fluoride (PVDF) membrane (Immunobilon-P, $0.45 \mathrm{~mm}$; Millipore, Billerica, MA, USA) using the TE 77 Semi-Dry Transfer Unit (GE Healthcare Life Sciences, Buckinghamshire, UK). The membranes were blocked with $5 \%$ non-fat skim milk in Tris-buffered saline containing $0.1 \%$ Tween 20 (TBS-T, pH 7.4) at room temperature for $1 \mathrm{~h}$. Then, each membrane was incubated with primary antibody (1:1000 dilution) for overnight at $4^{\circ} \mathrm{C}$, washed 5 times for 10 min each time with TBS-T, and incubated with HRP-conjugated secondary antibody (1:2000 dilution)

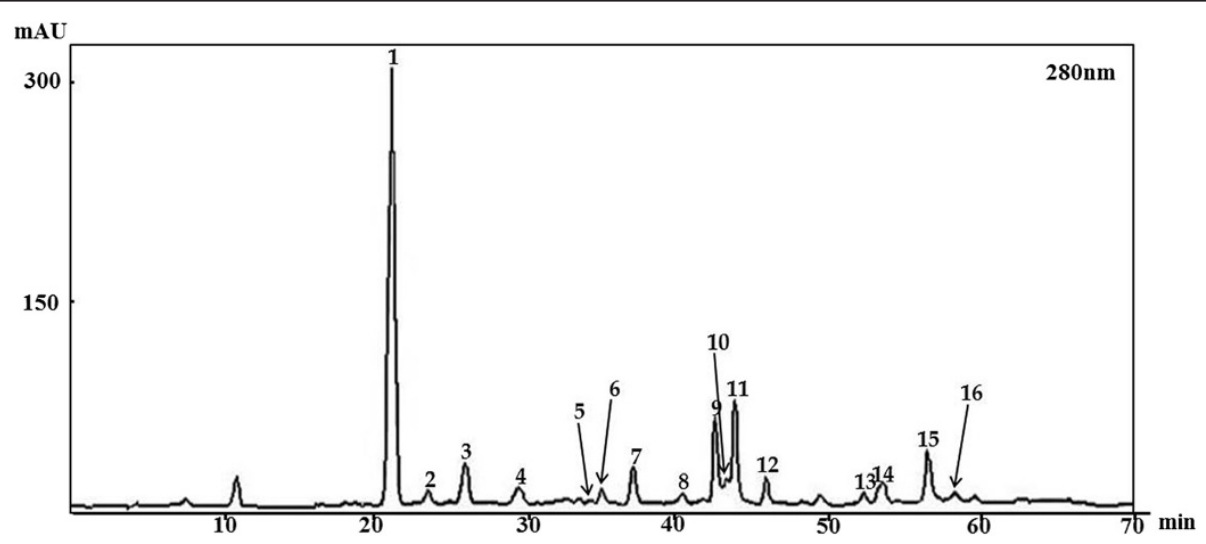

Figure 1 High performance liquid chromatography chromatogram. Totally 16 flavonoid compounds identified from Korean S. baicalensis G. at $280 \mathrm{~nm}$ and that's listed in Table 1. 
Table 1 Spectral data of the 16 flavonoids identified from Korean S. baicalensis G. using HPLC-MS/MS

\begin{tabular}{|c|c|c|c|c|c|}
\hline No & Compound & Rt (min) & {$[\mathrm{M}-\mathrm{H}]^{-} /[\mathrm{M}+\mathrm{H}]^{+}$} & MS/MS & ${ }^{\mathrm{a}}$ Quantity (mg/kg) \\
\hline 1 & Pentahydroxyflavanone derivative & 20.64 & 629 & 303285275217201177149125 & $212.543 \pm 1.074$ \\
\hline 2 & Pentahydroxyflavanone & 23.49 & 303 & 303285275259217193177149125109 & $16.670 \pm 0.188$ \\
\hline 3 & Viscidulin I-O- diglucoside & 25.98 & 625 & 301283273258229185151125 & $21.220 \pm 0.440$ \\
\hline 4. & Pentahydroxyflavone & 29.31 & 301 & 301283269259240191179161139124121109 & $17.657 \pm 0.204$ \\
\hline 5 & N.I & 34.65 & $647(+)$ & 647501467347321303285 & - \\
\hline 6 & Viscidulin III -O-glucoside & 35.22 & 507 & 345330315 & - \\
\hline 7 & Tetrahydroxyflavone & 37.69 & 285 & 285268241217199177151133107 & $43.056 \pm 0.112$ \\
\hline 8 & Iridin & 40.20 & 521 & 383359344329313300285212 & $21.472 \pm 0.415$ \\
\hline 9 & Eriodictyol (4'-hydroxynaringenin) & 42.25 & $289(+)$ & 289271247179163153147 & $45.679 \pm 0.782$ \\
\hline 10 & Puerarin & 43.24 & 415 & 415295267253223 & $7.003 \pm 0.022$ \\
\hline 11 & Viscidulin III & 43.88 & $347(+)$ & 347332317314289286183169150142 & - \\
\hline 12 & Pentahydroxyflavone & 45.11 & 301 & 301283269241225197179165161139133124107 & $20.622 \pm 0.036$ \\
\hline 13 & N.I & 52.55 & 675 & 675529481361335317285 & - \\
\hline 14 & Baicalin & 53.67 & $447(+)$ & 447343271253225169149123105 & $3.035 \pm 0.013$ \\
\hline 15 & Scutellarein & 56.25 & 285 & 285267257239213195185167165137119117 & $21.017 \pm 0.133$ \\
\hline 16 & Isoscutellarein & 57.35 & 285 & 285267257241239229213185167165137119117 & $7.882 \pm 0.009$ \\
\hline
\end{tabular}

${ }^{a}$ Quantity data are the mean \pm SD of three replicates determinations by HPLC-UV method. N.I: Not Identified.

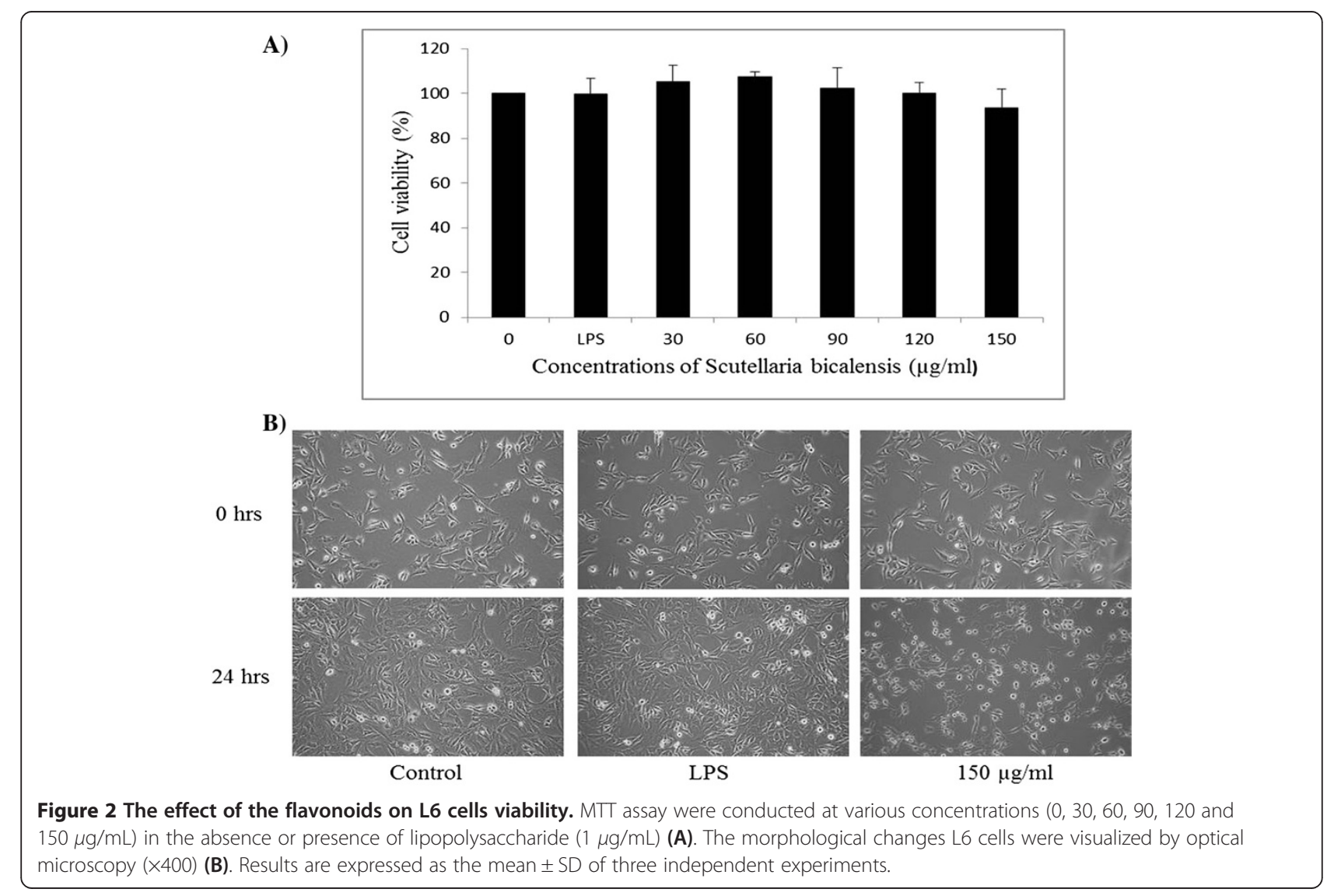


for $3 \mathrm{~h}$ at room temperature. Each membrane was washed 5 times for 10 min each time with TBS-T. The membranes were developed using an enhanced chemiluminescence (ECL) kit (GE Healthcare Life Sciences, Buckinghamshire, UK).

\section{Gene ontology (GO) analysis}

The Spot identities were submitted to GORetriever (http:// www.agbase.msstate.edu/) to obtain the GO annotations. If no annotation was returned, GOanna was used to retrieve
GO annotations assigned depending on the sequence similarities. The resulting annotations were summarized based on the GOA and whole proteome GOSlim set using GOSlimViewer [21]. These obtained results were exported to an Excel file and percentile calculations were done. The data is presented pie chart form to ease understanding.

\section{Statistical analysis}

The obtained results were expressed as the mean \pm standard deviation. Differences between the control, LPS
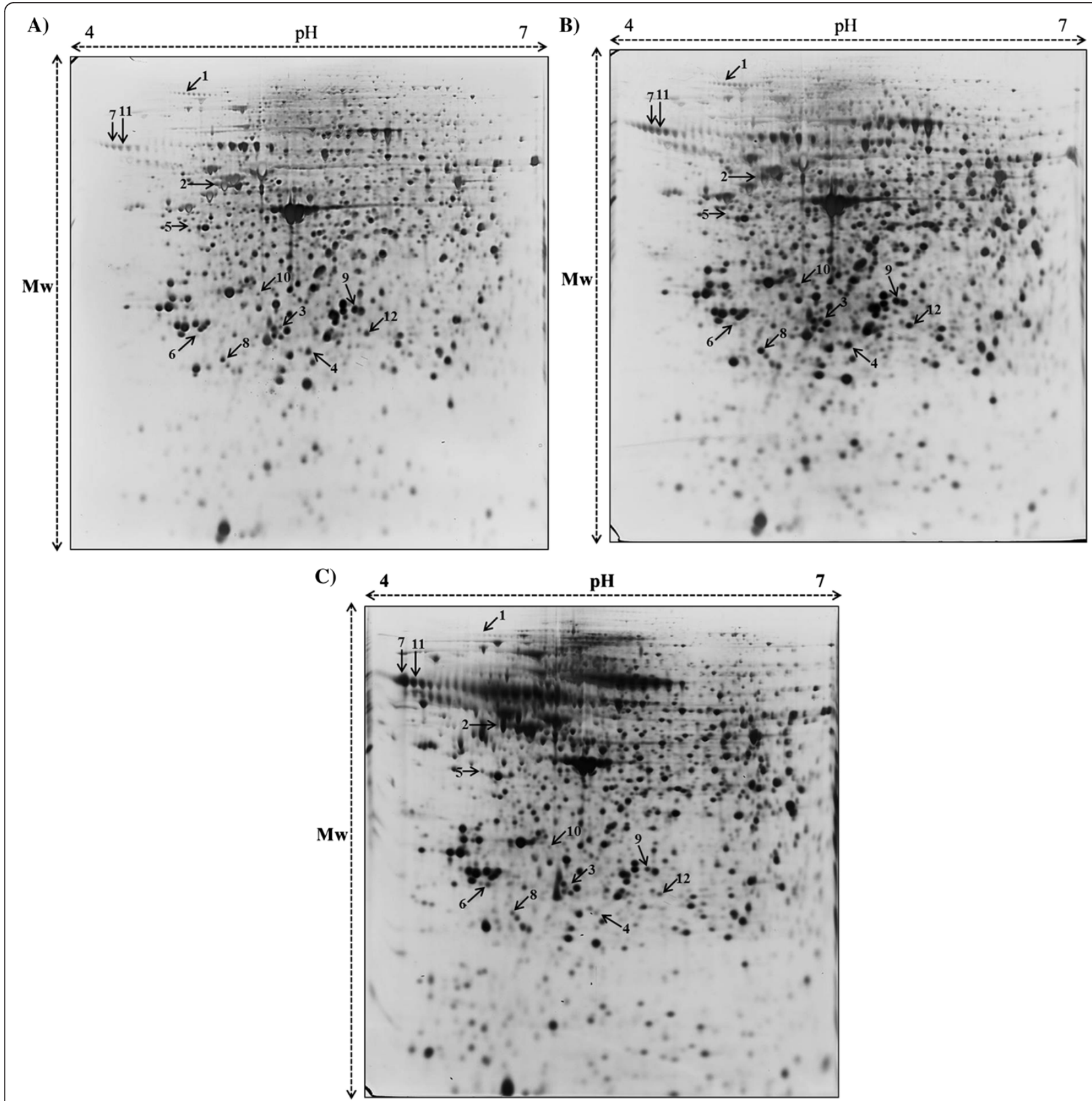

Figure 3 Protein profiles of L6 cells of (A) the control, (B) LPS treated and (C). $150 \mathrm{\mu g}$ of flavonoid treated groups. Proteins were separated on $\mathrm{pH} 4-7,17 \mathrm{~cm}$ linear IPG strips in the first dimension and 12\% SDS-PAGE in the second dimension. The gels were silver stained. 
Table 2 List of proteins identified from LPS stimulated L6 cells after flavonoids treatment by MALDI-TOF MS

\begin{tabular}{|c|c|c|c|c|c|c|c|}
\hline Spot no & Accession number ${ }^{1}$ & Protein name $^{1}$ & $\begin{array}{c}\text { Theoretical } \\
\mathrm{Mr}(\mathrm{Da})^{1}\end{array}$ & $\begin{array}{l}\text { Theoretical } \\
\text { pl value }^{1}\end{array}$ & $\begin{array}{l}\text { Matched } \\
\text { peptides }\end{array}$ & $\begin{array}{l}\text { Sequence } \\
\text { coverage }\end{array}$ & $\begin{array}{c}\text { Mowse } \\
\text { score }^{2} \\
\end{array}$ \\
\hline 1 & Q9QXU8 & Cytoplasmic dynein 1 light intermediate chain 1 & 56985 & 6.13 & 8 & 16 & 61 \\
\hline 2 & P31000 & Vimentin & 53757 & 5.06 & 26 & 52 & 108 \\
\hline 3 & Q7TST9 & T-box transcription factor TBX3 & 79684 & 7.72 & 8 & 12 & 51 \\
\hline 4 & P09812 & Glycogen phosphorylase, muscle form & 97725 & 6.91 & 20 & 25 & 58 \\
\hline 5 & Q29RW1 & Myosin-4 & 223653 & 5.58 & 33 & 17 & 56 \\
\hline 6 & Q9J113 & Prolactin-2A1 & 26148 & 6.44 & 7 & 29 & 51 \\
\hline 7 & Q9JHZ4 & GRIP1-associated protein 1 & 96300 & 5.17 & 10 & 13 & 54 \\
\hline 8 & Q8CGR3 & Alpha-S2-casein-like B & 20004 & 9.62 & 7 & 43 & 53 \\
\hline 9 & P02770 & Serum albumin & 70682 & 6.09 & 16 & 28 & 76 \\
\hline 10 & P14668 & Annexin A5 & 35779 & 4.93 & 16 & 45 & 79 \\
\hline 11 & Q07936 & Annexin A2 & 38939 & 7.55 & 14 & 49 & 62 \\
\hline 12 & P07150 & Annexin A1 & 39147 & 6.97 & 12 & 42 & 57 \\
\hline
\end{tabular}

${ }^{1}$ Accession number, protein name, theoretical molecular weight (Da) and pl from SWISS-PROT database identified by MALDI-TOF/MS.

${ }^{2}$ Score is $-10^{*} \log (p)$, where $p$ is the probability that the observed match is a random event, Protein scores greater than 51 are considered to be significant $(p<0.05)$.

and flavonoids treated groups were determined using one-way analysis of variance followed by a Student's $t$ test with $\mathrm{p}<0.05$ as the limit of significance. All statistical analyses were performed using SPSS software (SPSS for Windows, ver. 10.0; SPSS Inc. Chicago, IL, USA).

\section{Results}

\section{Quantification and characterization of flavonoids from Scutellaria baicalensis $\mathrm{G}$}

Flavonoids were isolated from Korean S. bicalensis G. using HPLC-MS/MS. totally 16 peaks were identified based on the HPLC retention time, molecular ion masses and the ultraviolet-visible spectra of standard compounds in a library. It was confirmed according to the peaks of HPLC chromatogram, that flavonoid components were in the extract at $280 \mathrm{~nm}$ (Figure 1). These flavonoid compounds are the essential components present in Korean S. baicalensis G. The mass-spectral and quantification data are presented in Table 1.

\section{Effects of flavonoids on L6 cells viability}

To determine the cytotoxic effects of the flavonoids on L6 cells, MTT assay was performed after treated with flavonoids at various concentrations (30, 60, 90, 120 and $150 \mu \mathrm{g} / \mathrm{mL}$ ) and incubated the cells for $24 \mathrm{~h}$ in the presence or absence of LPS $(1 \mu \mathrm{g} / \mathrm{mL})$. The results showed that LPS $(1 \mu \mathrm{g} / \mathrm{mL})$ and flavonoids of $30-150 \mu \mathrm{g} / \mathrm{mL}$ has no cytotoxicity to L6 cells but cell viability was start to decrease at $150 \mu \mathrm{g} / \mathrm{mL}$ (Figure 2A). Therefore, flavonoids concentrations up to $150 \mu \mathrm{g} / \mathrm{mL}$ were used for subsequent experiments. The cell morphology of L6 cells after flavonoids treatment in the presence or absence of LPS $(1 \mu \mathrm{g} / \mathrm{mL})$ were monitored under optical microscopy $(\times 400)$ after $24 \mathrm{~h}$ incubation (Figure $2 \mathrm{~B})$.

\section{2-DE and MALDI-TOF/MS}

The $150 \mu \mathrm{g}$ of total proteins from the L6 cells of the control, LPS treated, and flavonoid treated groups were extracted and resolved by $18 \mathrm{~cm}, \mathrm{pH} 4-7$ IPG strips in the first dimension and 12\% SDS-PAGE in the second dimension. Approximately 500 protein spots were detected in these silver-stained 2-DE maps. All protein spots exhibited molecular weights (MWs) of 10-175 kDa. The differences in the spot intensity were identified as quantitative changes. A total of 26 differentially expressed

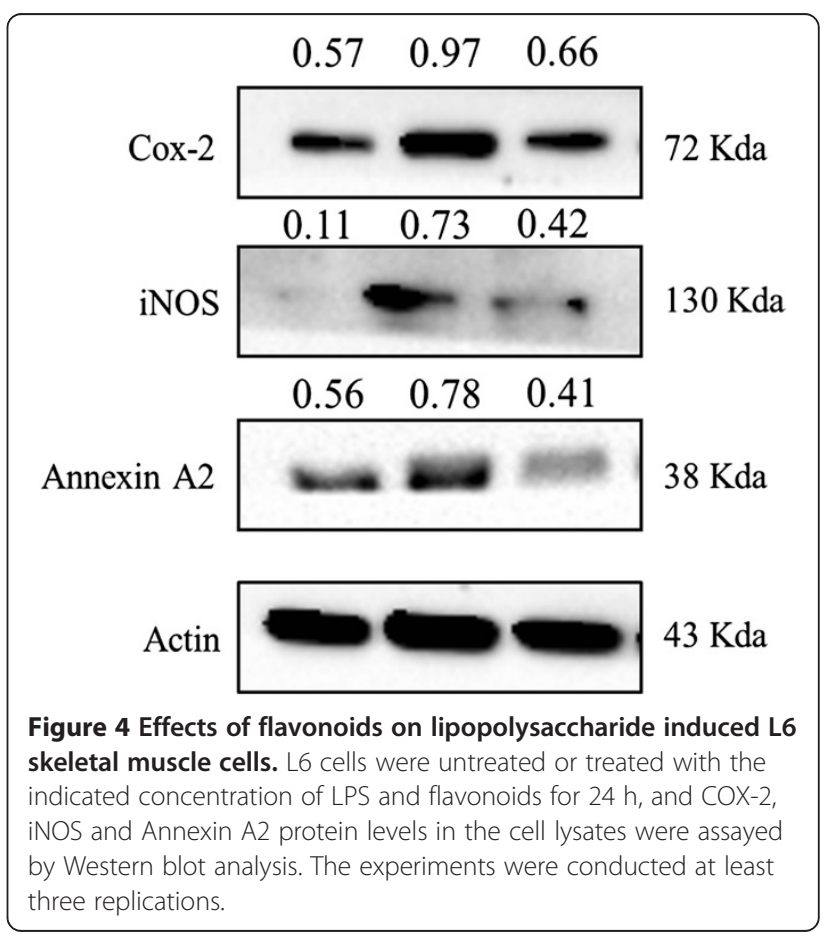


protein spots were identified (more than two-fold was considered significant, $\mathrm{p}<0.05$ ) (Figure 3 ), and 12 were successfully detected by MALDI-TOF/MS. The identified proteins name, accession number, number of matching peptides, theoretical isoelectric point (pI), molecular weights, sequence coverage and expression patterns in L6 cells were listed in Table 2 . The majority of the proteins were involved in inflammatory responses such vimentin (Vim), T-box transcription factor TBX3 (Tbx3), annexin A1 (Anxa1), annexin A2 (Anxa2) and annexin A5 (Anxa5).
Effect of flavonoids on expression of COX-2, iNOS and Annexin A2 proteins in LPS-stimulated L6 skeletal muscle cells

The effect of flavonoids on the expression of COX-2 and iNOS proteins were determined by western blot. In LPSstimulated L6 skeletal muscle cells, the expression of COX-2 and iNOS proteins were remarkably increased and pretreatment with flavonoid $(150 \mu \mathrm{g} / \mathrm{mL})$ attenuated protein expression (Figure 4). These results were suggest that flavonoids can inhibit LPS-induced inflammation by

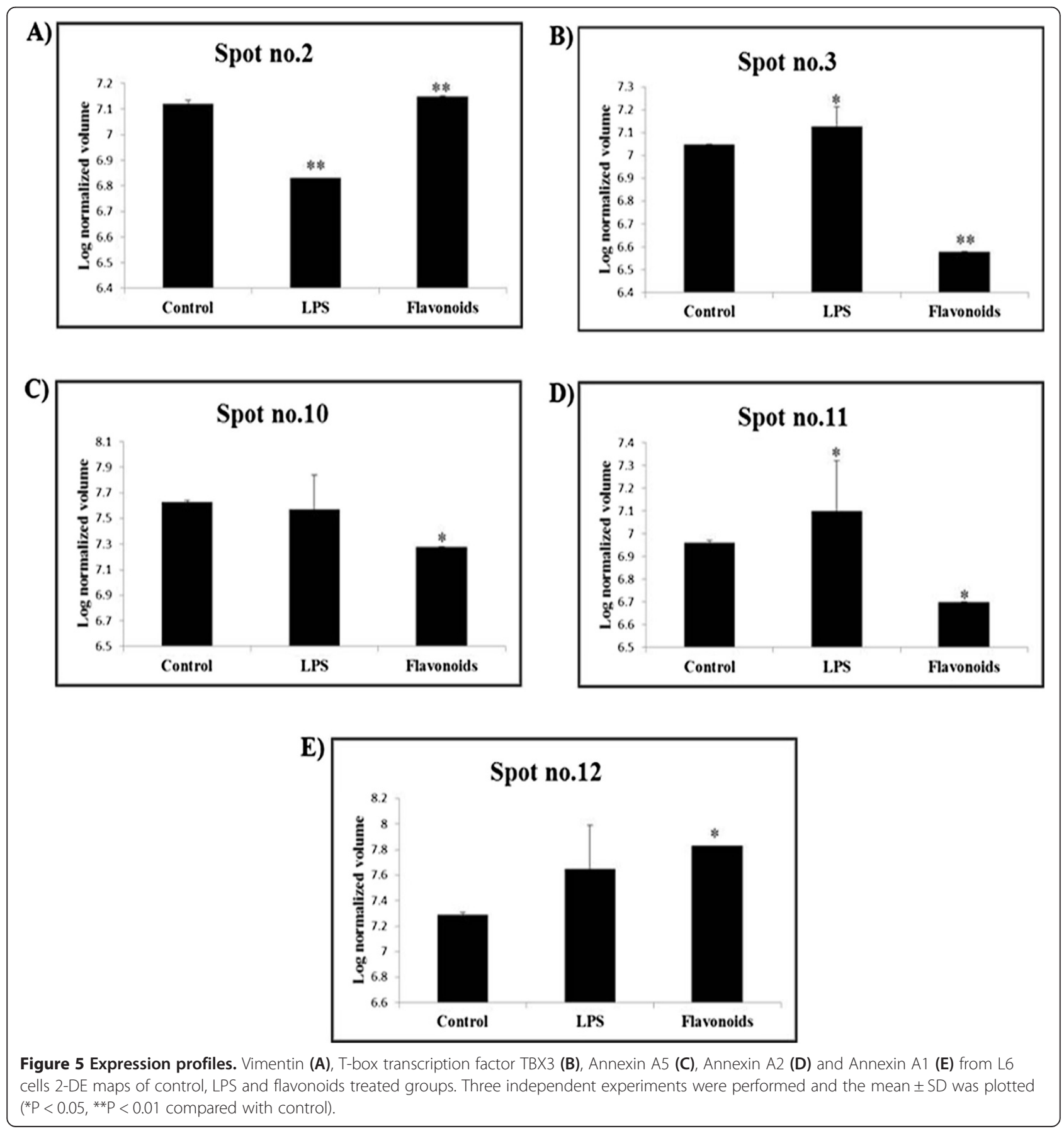


suppression COX-2 and iNOS expression at translational levels. Moreover, an anti-inflammatory protein, Anxa2 (unique annexins) expression was increased in LPStreated cells and, inhibited by flavonoids in LPS stimulated L6 skeletal muscle cells (Figures 4 and 5D). These results consistent with 2-DE results that LPS can induce inflammation in L6 cells by increasing Anxa2 protein and, that can be inhibited by flavonoids which isolated from S. baicalensis $\mathrm{G}$.

\section{GO analysis}

The most notable functional categories in relation to the protein expression pattern are shown in Figure 6 . The strongest associations were with biological processes (44\%) (GO: 0008150). Another 15\% of the associations were with anatomical structure development (GO: 0048856), whereas 5.5\% were associated with cell differentiation (GO: 0030154) and 4.5\% with transport (GO: 0006810).

\section{Discussion}

S. baicalensis $\mathrm{G}$. has been used as traditional herbal medicine in Asian countries because of its medicinal properties including anti-viral, anti-microbial, anti-inflammatory and anti-cancer properties [22,23]. In the current study, the anti-inflammatory effects of flavonoids isolated from $S$. baicalensis G. in LPS stimulated L6 skeletal muscle cells using proteome techniques. The western blot results shows that the expression of COX-2 and iNOS proteins were remarkably increased by LPS and pretreatment with flavonoid $(150 \mu \mathrm{g} / \mathrm{mL})$ attenuated protein expression in LPS-stimulated L6 skeletal muscle cells. These data suggests that flavonoids can inhibit inflammation by suppression of LPS-induced COX-2 and iNOS expression. Totally, 12 differentially expressed proteins were identified in L6 skeletal muscle cells after treated with LPS alone and combined with flavonoids using 2-DE coupled with MALDI-TOF/MS analysis (Figure 3 and Table 2). Proteomic analysis revealed that identified proteins were the involved in inflammatory responses due to flavonoids from S. baicalensis G. effects.

Firstly, vimentin expression is decreased by LPS and increased by flavonoids in L6 skeletal muscle cells (Figure 5A). It has been reported that vimentin is secreted by activated human macrophages and that's involved in immune functions of this cell type, as extracellular vimentin was found to be involved in bacterial killing and the generation of oxidative metabolites [24]. Schietke et al. [25] have demonstrated that mutations in vimentin were found to disrupt the cytoskeleton in fibroblasts and delay execution of apoptosis [25]. Another important protein, T-box transcription factor TBX3, is increased in LPS treated groups and decreased in flavonoids treated groups (Figure 5B). Previous studies have reported that T-box genes/proteins such as TBX2 and TBX3 are overexpressed in several neoplasms [26-28]. Also, Peres and prince [29] have demonstrated that increased levels of TBX3 are sufficient to promote tumor formation and invasion of non-tumorigenic melanoma cells in vivo [29]. These results suggest that flavonoids isolated from S. baicalensis G. protected the LPS induced inflammation in L6 cells.

The annexins are a family of phospholipid-binding proteins [30], and functionalize in the processes of endoand exocytosis, anti-inflammation, anticoagulation, signal

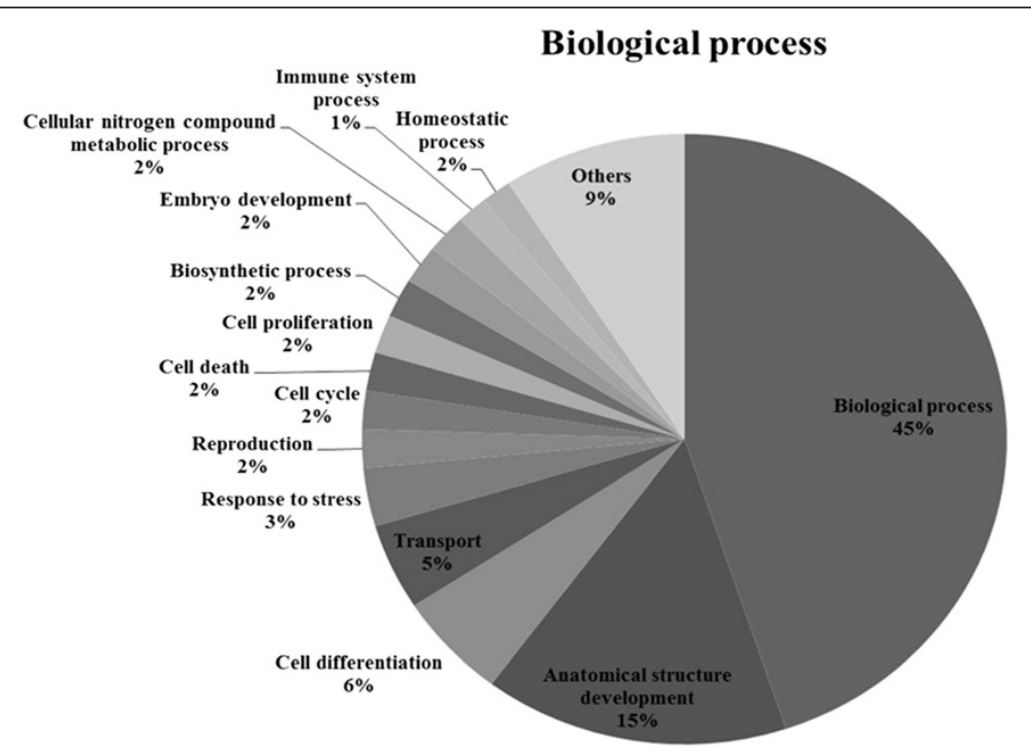

Figure 6 Gene ontology analysis (GO). GO analysis of the identified proteins in LPS stimulated L6 cells after treated with flavonoids. Pie charts representing the distribution of the identified proteins according to their biological function. This classification was produced based on an analysis using GOSlimViewer tool at Agbase (http://www.agbase.msstate.edu/). 
transduction, ion channel formation, cell proliferation, division and apoptosis, tumor development, invasion, metastasis and drug resistance [31,32]. In the current study, altered expression in L6 cells of Anxa1, Anxa2 and Anxa5 found in LPS and flavonoids treated groups compared to control. Annexin A1 (Anxa1), also known as lipocortin1 , an anti-inflammatory factor, originally reported as glucocorticoid-induced protein with anti-phospholipase activity that has been shown to regulate diverse cellular functions such as hormones secretion, vesiculation, inflammatory response, apoptosis and differentiation [33]. Also, Anxa1 exhibits profound inhibitory actions on leukocyte transmigration and activation, which leading to the resolution of inflammation [34]. Even though, Anxa1 is an anti-inflammatory protein, its significantly increased in flavonoids treated L6 cells expression, meanwhile no significant changes found in LPS treated groups (Figure 5E). Interestingly, previous study has reported that Anxa1 phosphorylation may have a role in the anti-inflammatory effects in response to drugs [35]. These results indicates that flavonoids from $S$. baicalensis $G$ have anti-inflammatory properties on LPS stimulated L6 cells by increasing the Anxa1 expression. However, further studies need to be proved the relationship between the flavonoids effects and Anxa1 phosphorylation.

It has been reported that Anxa5 up-regulation correlates with the inflammation-associated carcinogenesis of fibrosarcoma [36]. Also, Anxa5 might bind to phospholipid with high affinity on apoptotic cell membrane and it signals to immunity system [37]. In our study, Anxa5 expression was significantly decreased in flavonoids treated groups and no changes found in LPS treated groups (Figure 5C). In addition, Anxa2 is a unique among annexins and also an anti-inflammatory protein which involved in NF-kB signaling pathway [38]. The increased expression of Anxa2 was found in LPS treated groups and significantly decreased exprssions were observed in flavonoids treated groups (Figure 5D). These data suggest that LPS can induce inflammation in L6 cells by increasing Anxa5 and Anxa2 protein and, that can be inhibited by flavonoids which isolated from $S$. baicalensis $\mathrm{G}$.

\section{Conclusions}

In conclusion, we demonstrated that the anti-inflammatory effects of flavonoids from S. baicalensis G. on LPS stimulated L6 cells using proteomic approach. Flavonoids inhibited the expression of COX-2 and iNOS proteins in LPS-stimulated L6 skeletal muscle cells. Also, the 14 differentially expressed proteins were successfully identified by MALDI-TOF/MS that's were involved in inflammatory responses such vimentin, T-box transcription factor TBX3, annexin A1, annexin A2 and annexin A5. Further, the identified proteins were involved in inflammatory responses and, that Annexin A2 was validated by immune-blotting. Moreover, our study is the first proteome study provide the anti-inflammatory mechanism of flavonoids from S. baicalensis G. in LPS stimulated L6 cells. These research findings would be helpful to study further the muscle cell inflammatory mechanisms.

\section{Competing interests}

The authors declare that they have no competing interests.

\section{Authors' contributions}

JA-K and AK: Designed the study protocol, organized focus group discussion, collected and analyze other study data and prepared the final manuscript. HS-P, WGS and GE-H: Revised the study design, contributed in the statistical analysis and editing of manuscript. SY, HJ-L and EH-K: Participated in focus group discussion and collection of data and contributed in manuscript writing. SR, PS-Y and GS-K: Revised the study design, revised the results and final revision of manuscript for publication. All authors read and approved the final manuscript.

\section{Acknowledgement}

This study was supported by the National Research Foundation (NRF) of Korea grant funded by the Korean government (MEST) (No. 2012045015) and the National R\&D Program for Cancer Control, Ministry for Health, Welfare, and Family Affairs, Republic of Korea (No. 0820050).

\section{Author details}

'Department of Microbiology, College of Medicine, The Catholic University of Korea, Seoul 137-701, Republic of Korea. ${ }^{2}$ Research Institute of Life Science and College of Veterinary Medicine (BK21 plus project), Gyeongsang National University, Gazwa, Jinju 660-701, Republic of Korea. ${ }^{3}$ Department of Nursing Science, International University of Korea, Jinju 660-759, Republic of Korea.

Received: 15 March 2014 Accepted: 2 October 2014

Published: 7 October 2014

\section{References}

1. Butler AR: Traditional Chinese herbal medicine. Rep Proc Scott Soc Hist Med 1992, (93-94)(93-94):16-18.

2. Kumagai T, Muller Cl, Desmond JC, Imai Y, Heber D, Koeffler HP: Scutellaria baicalensis, a herbal medicine: anti-proliferative and apoptotic activity against acute lymphocytic leukemia, lymphoma and myeloma cell lines. Leuk Res 2007, 31(4):523-530.

3. Ono K, Nakane H, Fukushima M, Chermann JC, Barre-Sinoussi F: Inhibition of reverse transcriptase activity by a flavonoid compound, 5,6,7-trihydroxyflavone. Biochem Biophys Res Commun 1989, 160(3):982-987.

4. Ye F, Wang $H$, Jiang S, Wu J, Shao J, Cheng $X$, Tu Y, Zhang DY: Quality evaluation of commercial extracts of Scutellaria baicalensis. Nutr Cancer 2004, 49(2):217-222.

5. Parajuli P, Joshee N, Rimando AM, Mittal S, Yadav AK: In vitro antitumor mechanisms of various Scutellaria extracts and constituent flavonoids. Planta Med 2009, 75(1):41-48.

6. Baumann S, Fas SC, Giaisi M, Muller WW, Merling A, Gulow K, Edler L, Krammer PH, Li-Weber M: Wogonin preferentially kills malignant lymphocytes and suppresses T-cell tumor growth by inducing PLCgamma1- and Ca2+-dependent apoptosis. Blood 2008, 111(4):2354-2363

7. Li-Weber M: New therapeutic aspects of flavones: the anticancer properties of Scutellaria and its main active constituents Wogonin, Baicalein and Baicalin. Cancer Treat Rev 2009, 35(1):57-68.

8. Lu N, Gao Y, Ling Y, Chen Y, Yang Y, Gu HY, Qi Q, Liu W, Wang XT, You QD, Guo QL: Wogonin suppresses tumor growth in vivo and VEGF-induced angiogenesis through inhibiting tyrosine phosphorylation of VEGFR2. Life Sci 2008, 82(17-18):956-963.

9. Lee $\mathrm{DH}$, Lee $\mathrm{TH}$, Jung $\mathrm{CH}$, Kim YH: Wogonin induces apoptosis by activating the AMPK and p53 signaling pathways in human glioblastoma cells. Cell Signal 2012, 24(11):2216-2225

10. Huang KF, Zhang GD, Huang YQ, Diao Y: Wogonin induces apoptosis and down-regulates survivin in human breast cancer MCF-7 cells by modulating PI3K-AKT pathway. Int Immunopharmacol 2012, 12(2):334-341. 
11. Zhang M, Liu LP, Chen Y, Tian XY, Qin J, Wang D, Li Z, Mo SL: Wogonin induces apoptosis in RPMI 8226, a human myeloma cell line, by downregulating phospho-Akt and overexpressing Bax. Life Sci 2013, 92(1):55-62.

12. Kim YO, Leem K, Park J, Lee P, Ahn DK, Lee BC, Park HK, Suk K, Kim SY, Kim H: Cytoprotective effect of Scutellaria baicalensis in CA1 hippocampal neurons of rats after global cerebral ischemia. J Ethnopharmacol 2001, 77(2-3):183-188.

13. Wu B, Li J, Huang D, Wang W, Chen Y, Liao Y, Tang X, Xie H, Tang F: Baicalein mediates inhibition of migration and invasiveness of skin carcinoma through Ezrin in A431 cells. BMC Cancer 2011, 11:527-2407-11-527.

14. Chen S, Ruan Q, Bedner E, Deptala A, Wang X, Hsieh TC, Traganos F, Darzynkiewicz Z: Effects of the flavonoid baicalin and its metabolite baicalein on androgen receptor expression, cell cycle progression and apoptosis of prostate cancer cell lines. Cell Prolif 2001, 34(5):293-304.

15. Chang WH, Chen CH, Lu FJ: Different effects of baicalein, baicalin and wogonin on mitochondrial function, glutathione content and cell cycle progression in human hepatoma cell lines. Planta Med 2002, 68(2):128-132

16. Gao J, Morgan WA, Sanchez-Medina A, Corcoran O: The ethanol extract of Scutellaria baicalensis and the active compounds induce cell cycle arrest and apoptosis including upregulation of p53 and Bax in human lung cancer cells. Toxicol Appl Pharmacol 2011, 254(3):221-228.

17. Pan TL, Wang PW, Leu YL, Wu TH, Wu TS: Inhibitory effects of Scutellaria baicalensis extract on hepatic stellate cells through inducing G2/M cell cycle arrest and activating ERK-dependent apoptosis via Bax and caspase pathway. J Ethnopharmacol 2012, 139(3):829-837.

18. Park KI, Park HS, Kang SR, Nagappan A, Lee DH, Kim JA, Han DY, Kim GS: Korean Scutellaria baicalensis water extract inhibits cell cycle G1/S transition by suppressing cyclin D1 expression and matrixmetalloproteinase-2 activity in human lung cancer cells. J Ethnopharmacol 2011, 133(2):634-641.

19. Hong GE, Kim JA, Nagappan A, Yumnam S, Lee HJ, Kim EH, Lee WS, Shin SC, Park HS, Kim GS: Flavonoids Identified from Korean Scutellaria baicalensis Georgi inhibit inflammatory signaling by suppressing activation of NF- kappa B and MAPK in RAW 264.7 cells. Evid Based Complement Alternat Med 2013, 2013:912031

20. Shevchenko A, Wilm M, Vorm O, Mann M: Mass spectrometric sequencing of proteins silver-stained polyacrylamide gels. Anal Chem 1996, 68(5):850-858

21. McCarthy FM, Wang N, Magee GB, Nanduri B, Lawrence ML, Camon EB, Barrell DG, Hill DP, Dolan ME, Williams WP, Luthe DS, Bridges SM, Burgess SC: AgBase: a functional genomics resource for agriculture. BMC Genomics 2006, 7:229

22. Huang ST, Wang CY, Yang RC, Chu CJ, Wu HT, Pang JH: Wogonin, an active compound in Scutellaria baicalensis, induces apoptosis and reduces telomerase activity in the HL-60 leukemia cells. Phytomedicine 2010, 17(1):47-54.

23. Wang CZ, Li XL, Wang QF, Mehendale SR, Yuan CS: Selective fraction of Scutellaria baicalensis and its chemopreventive effects on MCF-7 human breast cancer cells. Phytomedicine 2010, 17(1):63-68.

24. Mor-Vaknin N, Punturieri A, Sitwala K, Markovitz DM: Vimentin is secreted by activated macrophages. Nat Cell Biol 2003, 5(1):59-63.

25. Schietke R, Brohl D, Wedig T, Mucke N, Herrmann H, Magin TM: Mutations in vimentin disrupt the cytoskeleton in fibroblasts and delay execution of apoptosis. Eur J Cell Biol 2006, 85(1):1-10.

26. Vance KW, Carreira S, Brosch G, Goding CR: Tbx2 is overexpressed and plays an important role in maintaining proliferation and suppression of senescence in melanomas. Cancer Res 2005, 65(6):2260-2268.

27. Sinclair CS, Adem C, Naderi A, Soderberg CL, Johnson M, Wu K, Wadum L, Couch VL, Sellers TA, Schaid D, Slezak J, Fredericksen Z, Ingle JN, Hartmann L, Jenkins RB, Couch FJ: TBX2 is preferentially amplified in BRCA1- and BRCA2-related breast tumors. Cancer Res 2002, 62(13):3587-3591.

28. Mahlamaki EH, Barlund M, Tanner M, Gorunova L, Hoglund M, Karhu R, Kallioniemi A: Frequent amplification of $8 q 24,11 q, 17 q$, and 20q-specific genes in pancreatic cancer. Genes Chromosomes Cancer 2002, 35(4):353-358.

29. Peres J, Prince S: The T-box transcription factor, TBX3, is sufficient to promote melanoma formation and invasion. Mol Cancer 2013, 12(1):117-4598-12-117.
30. Raynal P, Pollard HB: Annexins: the problem of assessing the biological role for a gene family of multifunctional calcium- and phospholipid-binding proteins. Biochim Biophys Acta 1994, 1197(1):63-93.

31. Zhang X, Liu S, Guo C, Zong J, Sun MZ: The association of annexin A2 and cancers. Clin Transl Oncol 2012, 14(9):634-640.

32. Wu N, Liu S, Guo C, Hou Z, Sun MZ: The role of annexin A3 playing in cancers. Clin Transl Oncol 2013, 15(2):106-110.

33. Sena A, Grishina I, Thai A, Goulart L, Macal M, Fenton A, Li J, Prindiville T, Oliani SM, Dandekar S, Goulart L, Sankaran-Walters S: Dysregulation of anti-inflammatory annexin A1 expression in progressive Crohns Disease. PLOS ONE 2013, 8(10):e76969.

34. Chatterjee BE, Yona S, Rosignoli G, Young RE, Nourshargh S, Flower RJ, Perretti M: Annexin 1-deficient neutrophils exhibit enhanced transmigration in vivo and increased responsiveness in vitro. J Leukoc Biol 2005, 78(3):639-646.

35. D'Acunto CW, Gbelcova H, Festa M, Ruml T: The complex understanding of Annexin A1 phosphorylation. Cell Signal 2014, 26(1):173-178.

36. Peng B, Guo C, Guan H, Liu S, Sun MZ: Annexin A5 as a potential marker in tumors. Clin Chim Acta 2014, 427:42-48.

37. Dumont EA, Reutelingsperger CP, Heidendal G, Hofstra L: Bringing cell death alive. Cardiovasc Toxicol 2003, 3(3):207-218.

38. Lin L, Wu C, Hu K: Tissue plasminogen activator activates NF-kappaB through a pathway involving annexin $A 2 / C D 11 b$ and integrin-linked kinase. J Am Soc Nephrol 2012, 23(8):1329-1338.

doi:10.1186/1472-6882-14-379

Cite this article as: Kim et al.: Proteome profiling of lipopolysaccharide induced L6 rat skeletal muscle cells response to flavonoids from Scutellaria baicalensis Georgi. BMC Complementary and Alternative Medicine 2014 14:379

\section{Submit your next manuscript to BioMed Central and take full advantage of:}

- Convenient online submission

- Thorough peer review

- No space constraints or color figure charges

- Immediate publication on acceptance

- Inclusion in PubMed, CAS, Scopus and Google Scholar

- Research which is freely available for redistribution 